Moore, S. \& Stein, W. H. (1951). J. biol. Chem. 192, 663.

Moore, S. \& Stein, W. H. (1954a). F. biol. Chem. $211,893$.

Moore, S. \& Stein, W. H. (1954b). F. biol. Chem. 21x, 907.

Spackman, D. H., Stein, W. H. \& Moore, S. (1958). Analyt. Chem. 3o, i т go.

Synge, R. I.. M, (1951). Biochem. 7. 49, 642 .

Thomson, A. R. (1967). In Proc. 5th Technicon Colloquium on Amino Acid Analysis p. I 16. Domont, France: Technicon International Division.

Van Slyke, D. D., Dillon, R. T., MacFadyen, D. A. \& Hamilton, P. (I941). F. biol. Chem. 141, 627.

\title{
The determination of tryptophan in biological materials
}

By R. A. Evans, M. T. Nadeem Chaudry and A. G. S'Tephens, Department of Biochemistry and Soil Science, University College of North Wales, Bangor

The determination of tryptophan in solution may be accomplished by a variety of methods. These are based upon (I) ultraviolet spectroscopy, (2) spectrofluorimetry, (3) colorimetry of the reaction with $p$-dimethyl amino benzaldehyde, and (4) chromatography followed by colorimetry of the reaction with ninhydrin.

When these methods are applied to tryptophan occurring in protein-bound form in biological materials, problems arise which have not yet been solved on a batch basis, still less by automation. In plant materials, in particular, the presence of interfering substances causes irrelevant spectroscopic absorption and prevents the application of methods (I) and (2).

Method (3) has been widely applied. In the method of Spies \& Chambers (1949), the protein is solubilized by treatment with $19 \mathrm{~N}$-sulphuric acid. In the method of Miller (1967), hydrolysis with barium hydroxide is employed, while the method of Lombard \& de Lange ( $\mathrm{g}^{6} 5$ ) uses papain to hydrolyse the protein enzymatically. All these methods depend upon the specificity of the colour reaction. In method (4) ion-exchange chromatography has been automated and provides specificity, but the requirement for hydrolysis of the protein remains and cannot yet be automated.

Hydrolysis with sodium hydroxide instead of barium hydroxide avoids mechanical and absorptive losses since the acidified hydrolysate can be applied directly to the column. The application of corrections for hydrolytic losses based upon recovery of added tryptophan is questionable, in view of the different behaviour of free and protein-bound tryptophan to hydrolysis in the presence of some reducing agents.

\section{REFERENCES}

Lombard, J. H. \& de Iange, D. J. (1965). Analyt. Biochem. 1o, 260.

Miller, E. L. (1967). F. Sci. Fd Agric. 18, 381.

Spies, J. R. \& Chambers, D. C. (I949). Analyt. Chem. 2I, 1249.

\section{Automated analysis of peptides}

By W. Bolton, J. M. McNab and J. C. Blair, ARC Poultry Research Centre, King's Buildings, West Mains Road, Edinburgh 9

The results to be given were obtained with a Technicon peptide analyser (Catravas, 1964). In our system the peptides are separated on a cation exchange resin and the 